\title{
Developing E-Learning-Based English Material for Teaching the Tenth Grade Students of Light Vehicle Department at SMK N Bali Mandara
}

\author{
Widiantari, Ni Made Dwi Putri \\ English Education Department, Ganesha University of Education \\ putri.dwi455@gmail.com
}

\begin{abstract}
This study aimed at: (1) identifying e-learning based English materials which were needed by the tenth grade students of Light Vehicle Department at SMK N Bali Mandara; (2) identifying the design of the e-learning based English materials for the tenth grade students of Light Vehicle Department at SMK N Bali Mandara; (3) measuring the quality of the e-learning based English materials for the tenth grade students of Light Vehicle Department at SMK N Bali Mandara. This study applied Research and Development designed by Lee and Owens (2004). The data of the study were collected through document analysis, questionnaire, and expert judge. The results of the data from the document analysis and questionnaire were analyzed descriptively; the data from expert judge was analyzed quantitatively by using a formula proposed by Candiasa (2010). The result of the study showed that the tenth grade students of Light vehicle Department at SMK N Bali Mandara were still taught using general English and the students needed English materials which were developed in accordance with their expertise program. Thus, this study developed four topics based on the students' expertise, namely: 1) Describing Hand Tools; 2) Signs at the Workplace; 3) Stating Capabilities in Repairing Car; and 4) Inviting Customer. Each topic was designed using Moodle version 3.3.x and focused on improving the students' four language skills. Based on the result of expert judgment, the mean score from both judges was 92 and was categorized as good materials.
\end{abstract}

Keywords: e-learning, English material, R\&D

\section{Introduction}

English is one of the subjects which should be learned by both senior high school students (SMA) and vocational school student (SMK). For SMK students who are expected to work after they graduate, mastering English becomes a demand since most of job vacancies nowadays require English proficiency, both written and spoken, as one of the requirements. Moreover, the development of globalization era brings a strict competition among the job seekers. Therefore, the SMK students need to master English which is in accordance with their expertise for the sake of their career development.

English takes an important role in students' development. As it is mentioned in Standar Isi KTSP (BNSP, 2006) language has a central role in the development of intellectual, social and emotional support and learner success in learning all areas of study. Language learning is expected to help learners to be able to present ideas and feelings, participate in the community, and even find and use analytical capabilities and imagination. English as one of the subjects provides the students the ability to communicate in daily life context in accordance with the global demands, as well as it equips the students to develop communications to a higher level. Thus, the SMK students need specific English materials which can improve their ability to communicate in a daily context, especially the context which is related with their expertise program. However, in fact the SMK students are taught using general English materials, that is, English materials which is closely similar with the materials given for the SMA students.

SMK N Bali Mandara is one of the vocational schools in Buleleng regency that established in 2013 by Balinese government under the leadership of I Made Mangku Pastika. 
Here, the students were still taught using general English materials. It was supported by the result of preliminary observation conducted on Monday, February 6, 2017 at SMK N Bali Mandara. One of the English teachers at SMKN Bali Mandara, admitted that the students actually need specific English material to be learned, that is, the materials which are related to their expertise program. Due to the syllabus applied in this school which is used as the guidance for the teacher in the teaching and learning process, thus the teacher just provides the general English materials for the students. Although, the students truly need English material which can help them when they have training section or work in the real work field later on. Based on the content of the board of national education standard (2006), the aims of studying English in SMK are: (1) mastering the basic knowledge and skill of English needed which can support the students in achieving the competency of their expertise program; (2) to be able to communicate using the mastery of English both in spoken and written on intermediate level. Then, it can be concluded that the SMK students require specific needs for mastering English as their subject learning. Learning material is considered as a significant aspect in learning English, since the learning material is the source of the students to learn the subject. Thus, the SMK students were learning English for specific purposes (ESP). Hutchinson and Waters (1987) stated that ESP is an approach to language teaching in which all decisions that related with the content and method should be based on the students' reason for learning. ESP is different from General English, that is, there is an existence of awareness of need in ESP. It means that in ESP, the learners, sponsors and teachers are aware why the students need English, in which the existence of the awareness will influence the content used in the language course. English which was learned by the SMK students was categorized as vocational English. According to Dudley and Evans (1998), vocational English concerned with the language of training for specific trades or occupations. Therefore, the materials which were used to teach the students should be based on students' need. But, there was an absence of English material which was specifically designed based on the students' need at SMK N Bali Mandara, especially for the tenth grade students of Light Vehicle Department.

Next, considering the constantly evolving digital era, it cannot be denied that Information and Communication Technology (ICT) has been becoming other basic need of human life which closely attaches everyday life of human, especially students' life. Based on the result of preliminary observation, it showed that almost $95 \%$ of the students at SMKN Bali Mandara had already skilled enough in utilizing mobile devices, such as smartphone, laptop, and computer. Then, the existence of ICT is believed as an important mean which can give highly contributions to the students in learning the knowledge they need. Thus, elearning could be introduced as a way in teaching and learning process.

E-learning refers to process of teaching and learning in which there is an integration of modern technology within. Srivatava (2013, p. 804) defines e-learning as the use of electronic media and information and communication technologies (ICT) in education/training. Srivatava (2013) proposes two types of e-learning, namely Synchronous and Asynchronous. Further, according to Condruz and Bacescu (2014), e-learning is defined as a learning process which is facilitated with a computer connected to internet. It means that in learning by using e-learning, any materials needed by the students are prepared by the teachers virtually. In addition, by using e-learning there are several benefits that could be got, if teachers apply elearning in their teaching and learning process. According to Pollard and Hillage (2001) there are several lists of the benefits of using e-learning, such as: 1) authorize learning activity becomes continual process; 2) authorize learning activity to be done anytime and anywhere; 3) authorize the teacher to update the material easily; 4) enhance students' self-assisted learning; 5) enhance students' interaction; 6) decreases teachers' intimidation; 7) offers ways to develop educational assessment; 8) academic and economic benefits; and 9) risk free. 
One of the e-learning platforms which is widely used by teachers in the teaching and learning process is Moodle. Moodle is an e-learning platform or Course Management System (CMS) or Learning Management System (LMS) that can be used and modified freely. This software is very easy to be used, especially for those who are familiar in operating internet such as browsing, chatting and sending e-mail. Marcais (2002) defined Moodle as a name of a program that can make the classroom to be extended onto the web. Then, according to Brandl (2005), Moodle is a CMS for online learning. Smith (2005 stated that Moodle is a free CMS which sometimes refers to VLA (Virtual Learning Environment) that requires webserver, PHP and a supported database to run. Further, Cole and Foster (2008) defined Moodle as an open source CMS that can be used by universities, colleges, schools, businesses, or educators who want to apply technology in their courses. Thus, Moodle as an e-learning platform could be used to develop the absence of English material which was in accordance with the needs of the tenth grade students of Light Vehicle Department at SMK N Bali Mandara.

This study aims at finding out the e-learning based English materials which are needed by the tenth grade students of Light Vehicle Department at SMK N Bali Mandara, the design of the e-learning based English materials for the tenth grade students of Light Vehicle Department at SMK N Bali Mandara, and the quality of the e-learning based English material for the tenth grade students of Light Vehicle Department at SMK N Bali Mandara.

\section{Methods}

This study follows R\&D design which is proposed by Lee and Owens (2004). There were five steps included in this design, namely: analysis, design, development, implementation and evaluation. However, as the researcher had limited time in conducting this study, thus the study was only conducted until the third step. The subjects of this study were the English teacher and students of the tenth grade of Light Vehicle Department at SMKN Bali Mandara. Then, the object of the study was developing e-learning based English materials for the tenth grade students of Light Vehicle Department at SMKN Bali Mandara. The methods which were used in collecting the data were document analysis, distributing questionnaire and expert judgment. While, the instruments used to support the data collection were documentation, questionnaire and expert judgment rubric. After the data were collected, further it was analyzed descriptively and quantitatively by using a formula and criteria proposed by Candiasa (2010).

\section{Findings}

\section{Finding and Discussion}

In order to find out the e-learning based English materials which are needed by the tenth grade students of Light Vehicle Department at SMK N Bali Mandara, the need analysis was conducted. The need analysis for this study was simply done by doing document analysis and distributing questionnaire for the tenth grade students of Light Vehicle Department and the English teacher. The questionnaire which was given for the students was used to gather the information about the students' needs toward the development of e-learning based English materials. Then, the questionnaire given for the English teacher was used to collect data about the e-learning based English materials need to be developed in form of e-learning. Based on the result of document analysis, there were four basic competencies which should be taught for the tenth grade students of Light Vehicle Department in the second semester. The first basic competency was explaining a situation in the present continuous form. The second basic competency was understanding memo, the transportation schedule, a simple menu and traffic signs. The third basic competency was understanding terms and simple sentence based on patterns. And the last basic competency was writing the simple invitation. From each basic 
competency, there were several indicators which should be achieved by the students in learning English. Further, in terms of the learning materials used by the teacher to teach the tenth grade students, the teacher used an English textbook entitled "English for SMK 1". The book was arranged with the learning outcomes for each topic, explanatory notes which consisted of list of language expression and materials, and activities that should be carried out by the students in accordance with the learning outcomes, such as fill in the blank, arrange scrambled words, multiple choice and essays. For listening section, there was no audio CD provided, in which the students just had to listen to their teacher if there was an activity for practicing listening. Further, the materials on the textbook did not provide any activities or vocabularies which were in accordance with the students' expertise program. In which, all the materials provided in the book were still general English material.

After conducting document analysis, questionnaires were distributed for the teacher and the tenth grade students of Light Vehicle Department. From the result questionnaire given for the students, it showed that the students had given positive responses toward the development of e-learning based English materials for helping them in learning English. Most of them agreed that the English materials which were in form of e-learning could bring benefits for them, and the accessibility for e-learning at the school was very possible, because the school had facilities which would support the application of e-learning. Further, the result of questionnaire given for the English teacher showed that the teacher suggested the researcher to develop four topics in form of e-learning based on the basic competencies which should be achieved by the students in the second semester. The topics involved materials about describing events, signs and symbols, capabilities and invitation.

After finding out the e-learning based English materials which were needed by the tenth grade students of Light Vehicle Department at SMK N Bali Mandara, the next step is designing the e-learning based English materials. The English materials for the tenth grade students of Light Vehicle Department at SMK N Bali Mandara were developed in form elearning, in which Moodle was the platform which was used to create the materials. The elearning based English materials were developed based on the syllabus applied at the school, in which the design of the materials was adjusted with the competencies which should be mastered by the students. In relation with the basic competencies that should be achieved by the students in the second semester, thus there were also four topics which were developed in the e-learning based English materials. The four topics developed could be seen in the homepage of the site which had been designed using Moodle, those were: 1) Describing Hand Tools; 2) Signs at the Workplace; 3) Stating Capabilities in Repairing Car; and 4) Inviting Customer.

There were several learning outcomes of each topic which should be achieved by the students by carrying out the activities designed in the topic. The activities in the e-learning based English materials were designed to practice the four language skills, namely: reading, writing, listening and speaking. Further, vocabularies activities were also designed to improve the students' knowledge toward unfamiliar word. Each topic consisted of eight activities which should be done by the students via online, in which for speaking practice, firstly the students were given example in form of audio and video talking about certain things, then they were required to do task in which they would have to make it in form of audio recording or video. Further, for listening section, the students were provided with audio and video to be listened to and then, they are required to answer the questions which were in form of essay, matching, or true false. Then, for reading section, passages and questions were provided to check students' comprehension in reading. Then, for writing, the students were provided with activities which were required the students to create something based on the topic, in which the examples were also provided for the students. Further, for the vocabulary practice, the 
students were asked to find out the meaning of listed vocabularies based on the topic developed.

After the design of the e-learning based English materials were developed, then the quality of the developed e-learning based English material was also examined. The quality of the developed e-learning based English materials was seen from the evaluation given by the experts, after conducting expert judgment step. In giving the evaluation to the product developed, a rubric had been prepared for the expert judges. The rubric was made based on theory of the criteria of good learning materials proposed by Tomlinson in 1998. The result of the calculation from both expert judges was $96>92 \geq 72$. It could be categorized to interval of $\mathrm{M}+1.8 \mathrm{SD}>92 \geq \mathrm{M}+0.6 \mathrm{SD}$. It means that the mean score was higher than $\mathrm{M}+0.6 \mathrm{SD}$. Therefore, based on the result of expert judgment, the e-learning based English materials for the tenth grade students of Light vehicle Department can be considered as good materials.

\section{Discussion}

This study was started by conducting need analysis for the students and the English teacher. According to Munby (1978) as cited in Hutchinson and Water (1987), needs analysis is a set of procedures in communication need processor (CNP), in which it consist of a set of questions about the key communication variables, such as topic, participants, medium, etc., that can be used to identify the target language needs of any group of learners. Need analysis was the step which was conducted to find out about the e-learning based English materials which were needed by the tenth grade students of Light Vehicle Department. Purnamasari (2015) in her study about developing English learning materials for Grade X students of Beauty Study Program, she also conducted need analysis before developing the materials. The needs analysis was conducted by distributing questionnaires to the students. The questionnaires were developed based on the principle of needs analysis proposed by Hutchinson and Waters (1987) that cover Target needs and Learning needs. But in this case, the need analysis was simply conducted through two methods of data collection which were used by the researcher, namely: document analysis and distributing questionnaire, in which the questionnaire were simply developed based on the syllabus applied at SMK N Bali Mandara.

In conducting document analysis, the syllabus and the textbook utilized by the teacher were analyzed by the researcher. Syllabus refers to a plan of what is to be achieved through teaching and learning process (Breen, 1984 as cited in Dewi 2016). According to BNSP (2006), syllabus covers the standard of competence, basic competencies, indicators, learning materials, learning activities, assessment, time allocation, and learning resources of what should be taught by the teachers to achieve the goal of teaching and learning process. Based on the document analysis, it resulted that the school has applied School-Based Curriculum (Kurikulum Tingkat Satuan Pendidikan) 2006. The syllabus analysis was intended to find the basic competencies which should achieved by the students. According to Standar Isi Untuk Satuan Pendidikan Dasar dan Menengah (2006: 111-112), Basic Competence is the outline presented in Standard of Competence which the materials coverage is more constrict than Standard of Competence. Thus, there were four basic competencies that should be covered in the materials learned by the students in the second semester, namely: 1) Explaining a situation in the present continuous form; 2) Understanding memo, transportation schedules, a simple menu and traffic signs; 3) Understanding terms and simple sentence based on patterns; and 4) Writing the simple invitation.

In relation with the basic competencies which should be mastered by the tenth grade students of Light vehicle Department in the second semester, then those four basic competencies had been used as the basic competencies in developing the materials in form of 
e-learning. But, since the developed materials would not become the main materials that would be used by the teacher later on, therefore, there was only one topic from each basic competency that was developed inform of e-learning. The topics were developed based on the English's teacher suggestion from the distributed questionnaire.

Besides analyzing the syllabus used for teaching the students of Light Vehicle Department, the researcher also analyzed the textbook used by the teacher. The teacher just used one textbook to teach all the tenth grade students at SMK N Bali Mandara. The textbook entitled English for SMK 1. This book was arranged with summaries of materials, examples of the topic taught, and exercises that practice the four language skills of the students. But, this book did not provide materials and exercises which were in accordance with the students' expertise program or students' need. The materials and exercises provides in the textbook were still general English materials, in which one textbook was used to teach all students at the school, even they were from different department or expertise program. While, vocational school students were students who learned English for specific purposes, that is, they learned English in order to have good communicative skills after they graduate from the vocational high school. Therefore, the materials which were used to teach the students were not appropriate. The book did not provide the topics or exercises which were in accordance with students' expertise program, that is, Light Vehicle Department.

After conducting document analysis, then the researcher constructed the two questionnaires. The questionnaires were given for the tenth grade students of Light Vehicle Department and the English teacher. From the result of need analysis of the tenth grade students of Light Vehicle Department, it could be concluded that the students truly needed the English materials which were in form of e-learning. The students agreed that they would get benefits if they could learn using e-learning, not just in terms of economic benefits, but also they could practice the materials taught continuously whenever and wherever they are. In addition, the school facilities would also support if the e-learning based English materials were developed. The school had provided the students with computer lab and good internet connection which could be utilized by the students to access the e-learning. It means that the accessible of e-learning for the students of Light Vehicle Department at SMK N Bali Mandara was very possible.

Further, the questionnaire of need analysis given for the English teacher was intended to gather the information about what topics which should be developed in form of e-learning. The questions in the questionnaire about the content which should be developed in form of elearning were constructed based on the syllabus which was applied at SMK N Bali Mandara. Based on the result of the questionnaire, the English teacher suggested the researcher to develop four topics from four basic competencies in the second semester. From each basic competency was developed one topic, in which the topics developed were adjusted with the students' expertise program. The four topics of e-learning based English materials which were needed by the tenth grade students of Light Vehicle Department at SMK N Bali Mandara based on the result of need analysis were: 1) Describing Hand Tools; 2) Signs at the Workplace; 3) Stating Capabilities in Repairing Car; and 4) Inviting Customer.

After conducting need analysis, the next step was designing the e-learning based English materials. The design was started by developing the blue print or the material design of e-learning based English materials. Since the researcher did not create new syllabus for the product, then the material design was developed in accordance with the existing syllabus used to teach the tenth grade students in the second semester. The material design of e-learning based English material for the tenth grade students of Light Vehicle Department contained several aspects namely: topic, skill, media, language function, language expression, 
vocabularies, structure, and exercises. Those aspects were distributed in each topic of the developed e-learning based English materials.

As the materials were developed in form of e-learning, Moodle was the platform which was used to developing the product. Moodle was a private website which allow teacher to conduct online courses to achieve the learning goal. It was supported by a research conducted by Ahmad et.al. (2011) about the effect of Moodle on students learning taking a course "Basic Computing Skills" offered for the foundation program at Sultan Qaboos University, Sultanate of Oman. The result revealed that however students had little experience of Moodle at the beginning of the course but headed for the end they had valued the significance and use Moodle as it is accessible from every internet enabled at any time. There were four topics which were developed by the researcher. The four topics were designed in the Moodle site. Since the developed materials were developed for the Light Vehicle Department students, then the topics were adjusted with the students' expertise program. The vocabularies in the materials were mostly related with common terms used by the students. Then, for every topic, there were activities which practiced the four language skills of the students. In addition, the students would also practice their vocabulary mastery. The names of the topic were also adjusted with the students' expertise program.

Each topic in the designed website was developed based on the basic competencies which were learned by the students in the second semester. There were three learning outcomes which the students were expected to be achieved in learning each developed topic. For every topic, there were eight activities which should be carried out by the students. The activities were intended to practice the four language skills of the students, namely: writing, reading, listening and speaking. In addition, there were also activities to practice vocabulary mastery of the students. The activities were designed in several types, such as matching quiz, true or false, essay, recorded role play, etc. For reading section, students were given text to be read, and then the questions were provided to be answered by the students. Then, for writing section, the students were given task, such as writing sentences and also short passages in which the examples had been provided. Further, for listening section, in each topic developed, the students were provided with audio or video to be observed. After listening the audio or watching the video, the students were required to write the important information from the video or audio, for example the language expression used by the models related with the topic. Besides that, the students were also provided with task, that is, True $(\mathrm{T})$ or False $(\mathrm{F})$, after they listened or watched the video. In practicing the students' vocabulary mastery, the researcher had designed activity such as vocabulary project, in which the students had to find the meaning of the words which were listed in the activity, besides that matching quiz also designed to practice the students' vocabulary mastery. That is, the students had to match pictures with the correct words, or match the words with correct meaning or function. Then, the activity which practiced the students' speaking skill was designed in which for each topic the students had to create a dialogue conversation or doing role play. The students were required to make an audio or video related with the topic they learned. According to Tomlinson (1998), good learning materials should help the students to develop their confidence. Therefore, the activity for practice students' speaking skill was designed where the students mostly required making dialogue conversation or doing role play, because when they did role play or dialogue conversation, they need to express themselves using the language they had learned confidently. For speaking activity in each topic, the students had to record it and when they had finished, they had to upload it to the submission link.

In conclusion, the developed e-learning based English materials were designed based on the guidance of syllabus applied at SMK N Bali Mandara for the tenth grade students in the second semester, the result of need analysis, and the criteria of good learning materials. 
There were several differences between this study with the previous study done by Arsana in 2015. The previous study had developed integrated computer based reading materials for the tenth grade students of SMK Pariwisata Ubud. The first difference was the product which was developed in the previous study was reading materials, while this study was not only focused on the reading materials, but materials for the four language skills. The previous study designed the materials using Microsoft Power Point 2007, while in this study the researcher designed the materials using e-learning platform, that is, Moodle. Yet, despite of those differences, both of the researchers developed materials for the tenth grade students of vocational school in the second semester.

Then, the quality of the developed e-learning based English materials for the tenth grade students of Light Vehicle Department at SMK N Bali Mandara were evaluated through expert judgment. There are two experts who contributed in the expert judgment. The first judge was Dra. Luh Putu Artini, MA, PhD. the lecturer of S1 Pendidikan Bahasa Inggris, at Ganesha University of Education, and the second judge was I Putu Ukik Sutamayasa, S.Pd., M.Pd the English teacher who taught the tenth grade students of Light Vehicle Department at SMK N Bali Mandara. Both expert judges were given expert judgment rubric which was developed based on the criteria of good learning material. The main aspect of the criteria of good learning materials was materials could achieve impact; materials could help learners to feel at ease; materials should help learners to develop confidence; and materials should be relevant and useful.

Based on the result of the calculation from both expert judges was $96>92 \geq 72$. It could be categorized to interval of $\mathrm{M}+1.8 \mathrm{SD}>92 \geq \mathrm{M}+0.6 \mathrm{SD}$. It means that the mean score was higher than $\mathrm{M}+0.6 \mathrm{SD}$. Therefore, based on the result of expert judgment, the elearning based English materials for the tenth grade students of Light Vehicle Department can be considered as good materials. Although the developed e-learning based English materials was categorized as good materials based on the result of expert judgment step, there were still some parts of the materials which need to be revised. Then, the developed product was revised based on the suggestion which were given by the expert judges. Thus, the result of expert judgment step showed that the developed e-learning based English material had fulfilled the criteria of good learning materials proposed by Tomlinson (1998).

From the first aspect, that is, the materials should achieve impact. According to Tomlinson (1998), the impact could be achieved when materials had a noticeable effect on students that was when the students' curiosity, interest, and attention were attracted. Achieving it, the material should have the characteristic of being novelty, variety, has attractive presentation, and has appealing content. Therefore, the English materials were designed in form of e-learning, in which it was new for the students. The material was also designed with high quality of pictures, audio, video and various types of task to avoid the feeling of bored. The content of the e-learning based English material was also designed contextually which were based on the students' expertise program and their daily life. Both of the expert judges agreed that the developed e-learning based English material was interesting and able to engage students' curiosity.

The second aspect was the materials should help the learners to feel at ease. Learning will run effectively when learners feel comfortable and relax. So, materials also had role to help the students to feel relax and enjoyed the learning process (Tomlinson, 1998). It could be achieved when the material used text or illustration that related to their daily life. Therefore, the material which was developed by the researcher used the materials which were related to students' daily life, for example: the picture of hand tools which were commonly used and seen by the students at the workplace. Moreover, the materials were also designed in accordance with the students' level. 
The third aspect was the materials should help learners to develop confidence. Students which being relaxed and has self-confident usually can learn faster. Tomlinson (1998) stated that it is better to attempt to build confidence through activities, in which the activities try to push the students slightly beyond their existing proficiency. It can be achieved by engaging the students in tasks which are problematic, but still achievable by them. It can also be done through encouraging the students to used and to develop their existing extralinguistic skills which involve their imagination, creativity or analytic. Then, in this study, the researcher tried to develop students' confidence through developing learning materials which were in form of e-learning, which can be operated by the students, even they did not have sufficient experience in learning using e-learning. It was because the developed e-learning based English materials were designed in easy navigation and simple layout to make the students feel at ease. Further, the activities designed in the e-learning, especially for speaking section also intended to develop students' confidence, since for the speaking activity, the students mostly required to express themselves by doing role play and dialogue conversation, in which it could encourage their imagination and creativity.

The forth aspect, what was being taught should be perceived by the learners as relevant and useful. According to Tomlinson (1998), materials can be relevant and useful for students if it is related to students' interest and to contextual tasks, which the students need to perform in the target language. By combining the implementation of ICT, that is the materials which were developed in form of e-learning and interesting activities in the developed learning materials, it had been able to motivate the students to learn. The activities in the elearning were also designed using pictures and vocabularies which were commonly used by the students in their daily life, in this case related with the students' expertise program. Moreover, both judges agreed that the content of the developed e-learning based English materials would be perceived as relevant and useful for the students.

In addition, the developed material was categorized as a very good material since it was developed in form of e-learning. Aktaruzzaman et al. (2011) had conducted a research related with Trends and Issues to integrate ICT in Teaching Learning for the Future World of Education. The findings revealed a significant result, in which it showed that educational technology has become essential to impart education. They combine the use of several ICTsinternet, video, audio, graphics, text, images, etc. to offer students a near live experience of what is learning. Mehdipur, et.al.(2013) who conducted a study about the benefits and challenges of mobile learning for education also revealed that mobile learning as a distance learning brought great benefits for the students include learning when it is needed, learning at any time, learning at any place and learner-centered content.

Thus, the quality of the developed e-learning based English materials for the tenth grade students of Light Vehicle Department at SMK N Bali Mandara was very high quality in which it can be seen from the total score given by the both expert judges from expert judgment step.

\section{Conclusion}

Based on the result of the study, it could be concluded that:

a. Based on the document analysis and questionnaire of need analysis to find out the elearning based English materials which were needed by the tenth grade students of Light Vehicle Department, it resulted that the students needed four topics to be developed as elearning based English materials. Those topics were based on the basic competencies which should be achieved by the students in the second semester. The topics were 1) Describing Hand Tools; 2) Signs at the Workplace; 3) Stating Capabilities in Repairing Car; and 4) Inviting Customer. 
b. The four topics were designed in form of e-learning. Moodle was the e-learning platform which was used to develop the materials. Each of the developed topics had two to three learning outcomes which should be achieved by the students. Eight activities were designed for each topic to achieve the learning outcomes. There were activities to practice the four language skills, such as reading, writing, listening and speaking. Text or passage was provided to practice students' reading skill. Further, for listening section, the students were provided with audio and video.

c. The quality of the developed e-learning based English materials was seen from the result of expert judgment step. The result of the calculation from both expert judges was $96>92 \geq$ 72. It could be categorized to interval of $\mathrm{M}+1.8 \mathrm{SD}>92 \geq \mathrm{M}+0.6 \mathrm{SD}$. It means that the mean score was higher than $\mathrm{M}+0.6 \mathrm{SD}$. Therefore, based on the result of expert judgment, the e-learning based English materials for the tenth grade students of Light vehicle Department can be considered as good materials.

\section{References}

Aktaruzzaman, M., Shamim, M., Clement, C. (2011). Trends and issues to integrate ICT in teaching learning for the future world of education. International Journal of Engineering \& Technology IJET-IJENS, 11(03), 114-119.

Arsana, S. P. (2015). Developing Integrated Computer Based Reading Material for The Tenth Grade Students of SMK Pariwisata Ubud in the Academic Year of 2014/2015. Unpublished Thesis. English Language Education Postgraduate Program: Ganesha University of Education.

Bitter, G. G., and Legacy, J. M. (2009). Using Technology in the Classroom ( $7^{\text {th }}$ ed). Boston: Pearson Education Inc.

BNSP. (2006). Standar kompetensi dasar SMK/MAK. Jakarta: Badan Standar Nasional Pendidikan.

Brandl, K. (2005). Retrieved November 7, 2016, from Are you ready to "Moodle"? : language learning and technology: http://llt.msu.edu/vol9num2/review1

Cole, J. \& Foster, H. (2008). Using Moodle: teaching with the popular open source course management system. United States of America: O’Reilly Community Press.

Condruz, M \& Bacescu. (2014). E-learning/m-learning - the new trend in foreign language teaching. Professional Communication And Translation Studies, 7(1), 159-166.

Dudley-Evans, T. (1997). Developments in English for specific purposes: A multi-disciplinary approach. Cambridge University Press.

Hutchinson, T. \& Waters, A. (1987). English for specific purposes: A learner-centered approach.Cambridge University Press.

Kasumajaya, I. D. M. B. (2015). Developing English Materials for Front Office Course for The Students of Hotel Accomodation of PPLP Dhyana Pura. Unpublished Thesis. English Language Education Postgraduate Program: Ganesha University of Education.

Lee, W.W. \& Owens, D. L. (2004). Multimedia-based Instructional Design. San Francisco: Preeiffer.

Marcais, T. (2002). Retrieved November 17, 2016, from Moodle an electronic classroom: http://docs.google.com/viewer?a=v\&q=cache:_G_W013F2SUJ:wbt.unitbv.ro/id8/file. php/1/Resure_Publice/Manuale_Moodle/Moodle1.5.3

Mehdipour, Y. \& Zerehkafi, H. (2013). Mobile learning for education: benefits and challenges. International Journal of Computational Engineering Research, 3(6), 93101 
Pollard, E. \& Hillage, J. (2001). Exploring E-Learning. United Kingdom: The Institute for Employment Study.

Srivastava, E \& Agarwa, N. (2013). E-learning: New trend in education and training. International Journal of Advanced Research , 1( 8), 797-810

Swales, John. (1992). Language for specific purposes. In W. Bright (Ed.),International encyclopedia of linguistics (Vol. 2, p. 300). New York, Oxford: Oxford University Press.

Tomlinson, B. (1998). Material Development in Language Teaching. United Kingdom: Cambridge University 